\title{
DELAYS AND BOTTLENECKS IN THE LICENSING PROCESS AFFECTING UTILITIES: THE ROLE OF IMPROVED PROCEDURES AND ADVANCE PLANNING
}

\author{
James T. RAMEY* AND JAMES P. MURRAY, JR.**
}

The existence of delays and bottlenecks in the administrative process is not a new phenomenon: it has vexed all levels of government and has required their continuing attention. Indeed, one of the goals sought through the establishment of the Administrative Conference of the United States' is that "regulatory activities and other federal responsibilities may be carried out expeditiously in the public interest." At its first meeting on May 27, 1968, the Committee on Licenses and Authorizations ${ }^{3}$ of the Administrative Conference established as its first priority concern the problem of undue delays in the full range of federal licensing proceedings. A primary action in this regard was to pursue from the point of view of licensing delays-as opposed to administrative delays in general-the 1966 survey conducted by the Subcommittee on Administrative Practice and Procedures of the Senate Judiciary Committee. A new survey letter was addressed to a number of organizations and practitioners closely associated with the licensing processes of the major regulatory agencies. While broadly seeking suggestions on the causes of and remedies for licensing delays, the

* Commissioner, United States Atomic Energy Commission. B.S. 1937, Amberst College; LL.B. 1941, Columbia University.

** Attorney, United States Atomic Energy Commission. B.S. 1949, Yale University; LL.B. 1952, Georgetown University.

1. The statutory basis for the Administrative Conference will be found at 5 U.S.C. $\S \S 1045-$ 1045(e) (1964). For a description of the Conference and its activities prior to the October 2122, 1969 plenary session, see Wozencraft, The Administrative Conference of the United States, 24 Bus. Law. 915 (1969).

2. 5 U.S.C. $\S 1045(\mathrm{e})(1964)$.

3. The initial members of the Committee were James T. Ramey, Commissioner, Atomic Energy Commission, Chairman; Donald C. Cook, President, American Electric Power Co., Inc.; James C. Langdon, Chairman, Texas Railroad Commission; F. Merritt Ruhlen, Hearing Examiner, Civil Aéronautics Board; Starr Thomas, Vice President-Law, Santa Fe Railway System; James B. Minor, Assistant General Counsel for Regulatiqn, Department of Transportation; and Edward Weinberg, Solicitor, Department of the Interior. Early in 1969 Mitchell Melich, Solicitor, Department of the Interior, replaced Mr. Weinberg.

4. Staff of Senate Comm. on the Judiciary, 89Th Cong., 2D Sess., Questionnaire Survey of Delay in Administrative Proceedings (Comm. Print 1966). 
letter also noted the Committee's specific interest in the question of whether "undue delay is being occasioned by court mandates appearing to require agencies to consider a broad range of alternative proposals, sites or applicants."

Intra-Committee discussion of the responses indicated that attempts at generalizing with respect to causes and remedies for licensing delays could prove misleading to the extent that a remedial technique proven helpful to one type of licensing in a specific agency might not be exportable to apparently similar licensing processes without substantial alteration. Bearing this caveat in mind and fortified by the encouragement received from responses to the survey letter, the Committee undertook a study of the question whether there was a potential for undue licensing delay because of the exploration of numerous alternatives in the adjudication of a particular licensing case. ${ }^{6}$ Following a brief discussion of this

5. The new survey letter contained fifteen specific Committee-developed ideas on which comments were welcomed. Pertinent among these were:

1. Require the submission of direct evidence in written form before the hearing begins so that the hearing examiner can make informed and early rulings on relevancy, both of the direct evidence submitted and on cross-examination, and thereby keep the record within reasonable proportions.

....

7. Require direct evidence to be filed with the application, so that the examiner will have had an opportunity to study it before pre-trial conference (this would require fairly specific aids to the applicant respecting admissibility and relevance, and, of course, could not prejudice later submissions when deemed appropriate by the examiner.)

....

10. Set limits on the number of witnesses to be heard for any given position or point of view.

11. To aid in the specification of issues and in the organization of the hearing, require trial briefs, opening statements, or both.

....

13. Do not admit as witnesses those who will merely state the policy position or views of the applicant. Committee on Licenses and Authorizations, Administrative Conference of the United States, Questionnaire on Undue Delay (Aug. 21, 1968).

6. The study was performed under the Committee's direction by the staff attorney of the Administrative Conference, Mr. David E. Kartalia, and eventuated in a recommendation to the Conference concerning "alternatives." Administrative Conference of the United States, Recommendation No. 15-Consideration of Alternatives in Licensing Procedures (Oct. 22, 1969) (115 Cong. Rec. 15193 (daily ed. Dec. 1, 1969)).

Another Committee study on a different aspect of delays resulted in another recommendation adopted at the October, 1969 plenary session of the Conference. Administrative Conference of the United States, Recommendation No. 14-Compilation of Statistics on Administrative Proceedings by Federal Departments and Agencies (Oct. 22, 1969) (115 CoNG. REC. 15192 (daily ed. Dec. 1, 1969)) The opening sentence of the recommendation reflects the tie-in with licensing delays:

Government agencies which conduct formal or informal rule-making proceedings or 
problem of alternatives and delay arising primarily from a growing opposition to power facilities on environmental grounds, this article will discuss the role of improved procedures and advance planning in a voiding or, at least, alleviating the delay problem.

\section{The Scenic Hudson Case and Consideration of Alternatives}

The case primarily responsible for giving rise to the concern for delays resulting from the consideration of the differing environmental and economic impacts of a large number of "alternative" plans is Scenic Hudson Preservation Conference $v$. FPC. In Scenic Hudson the Second Circuit reversed a decision of the Federal Power Commission to license the Consolidated Edison Company's proposed pumped-storage hydroelectric project at a scenic reach of the Hudson River known as Storm King Mountain. In remanding the matter the court stated that the Commission had "failed to make a thorough study of possible alternatives"s noting that "[t]he record as it comes to us fails markedly to make out a case for the Storm King project on, among other matters, costs, public convenience and necessity, and absence of reasonable alternatives." Examples mentioned by the court as alternatives to the Storm King project were "purchased peaking power"10 and various combinations of other alternative power sources such as gas turbines and interconnections."

Because the range of possible alternatives could in most cases be extensive, the scope of an agency's obligation under the Scenic

cases of adjudication which directly fix the rights and obligations of private persons (hereafter referred to as "proceedings") owe a special duty to the individuals affected and to the general public to manage their caseloads as efficiently as possible, to eliminate inordinate delays in the conduct of proceedings, and to work continuously toward improving the fairness, effectiveness, and economy of their procedures. Id. (footnote omitted).

7. 354 F.2d 608 (2d Cir. 1965), cert. denied, 384 U.S. 941 (1966).

8. Id. at 612 .

9. Id. at 624-25.

10. In his dissent, FPC Commissioner Ross stated:

In my opinion, the only true alternative that would likely be as economic as the proposed project would be purchased peaking power. There are two possibly differing sources; one would be purchasing pumped storage or normal hydro peaking which may be in the process of development in New England; or secondly, purchasing steam peaking power from new large scale thermal stations in Pennsylvania or in Appalachia. Consolidated Edison Co., 33 F.P.C. 428, 463 (1965).

11. 354 F.2d at $621-22$. 
Hudson doctrine is not clearly discernible..$^{2}$ As a practical matter, even an agency's consideration of all reasonable alternatives which might be conceived could result in considerable delay before any decision is reached on the licensing question. In this connection it is of interest that the FPC's proceedings on remand in Scenic Hudson had, as of December 1969, consumed some seventy-four hearing days and were still far from closed. ${ }^{13}$ The application for the license was filed on January 29, 1963.'4

\section{Recommendation of the Administrative Conference}

It seems clear that an overreaction by licensing agencies to the Scenic Hudson doctrine in an effort to make their decisions appealproof could introduce considerable unnecessary delay into the licensing processes of affected agencies. This conclusion underlies a recommendation on "Consideration of Alternatives in Licensing Procedures" presented by the Committee on Licenses and Authorizations to the third plenary session of the Conference on October 21 and 22, 1969. The text of the recommendation, as formally adopted by the Conference, reads as follows:

Court decisions, notably Scenic Hudson Preservation Conference v. FPC, have emphasized that in licensing cases the Federal Power Commission must explore and give proper consideration to possible alternatives to the specific plan proposed by the applicant. This principle may in the future be applied to other licensing agencies. Since the range of possible alternatives in any case can be extensive and in some cases virtually unbounded, ways must be sought to control the scope and duration of licensing proceedings within manageable limits while meeting the requirements of law.

\section{RECOMMENDATION}

Each agency which issues licenses, permits, or other forms of authorization, should seek to create procedures fitting its particular circumstances which will assure appropriate consideration of alternatives, where necessary, and at the same time will permit effective administration of that agency's licensing functions.

Because the various agencies must deal in their licensing procedures with many diverse subject matters, the Administrative Conference cannot specify a single rule and procedure for achieving this objective. Procedural techniques

12. The 1969 Annual Report of the Section of Public Utility Law of the ABA contains an interesting discussion by Arthur R. Seder. Jr. of an agency's duty to investigate and develop alternatives. Seder, Regulatory Activism-The Afternath of Scenic Hudson, in 1969 A BA Pub. Utility Law Section AnN. Rep. 3.

13. FPC Project No. 2338 (as of December 1969).

14. Id. 
which experience has shown useful in analogous situations and which an agency might consider include: (1) guidelines embodying a rule of reason concerning the number and character of alternatives to be considered in particular types of cases; (2) rules providing a point in time beyond which the issues in a proceeding will not be expanded to include additional alternatives except under compelling circumstances; (3) techniques, such as pre-hearing conferences and the filing of testimony in written form before trial, which tend to promote early identification of interested parties and important alternatives; and (4) placing responsibility upon the party or other person proposing an alternative to the applicant's proposal to make an appropriate threshold showing that the alternative deserves the agency's consideration. ${ }^{15}$

The recommendation seeks to identify a potential problem area in advance and to suggest some measures that might be used to avoid or minimize its magnitude. Flexibility is the theme of the recommendation, and maximum latitude for adaptation of the suggestions to the specific reeds of individual agencies is afforded.

None of the procedural techniques suggested are particularly novel, the first three enumerated having been employed before by one or another agency in analogous contexts. For example, with respect to rules reasonably limiting the alternatives to be considered-subdivision (1) of the recommendation-the experience of the Atomic Energy Commission is pertinent. Although reactor licenses are issued with regard to "the common defense and security and to protect the health and safety of the public,"16 the Atomic Energy Commission has promulgated a rule to the effect that a reactor license applicant need not specifically consider in its proposed reactor design the question of possible enemy.actions. ${ }^{17}$ The justification for the rule points out, inter alia, that a potential enemy's intentions "are matters speculative in the extreme" and that the safety features included for the public's protection could serve

\footnotetext{
15. Administrative Conference of the United States, Recommendation No. 15-Consideration of Alternatives in Licensing Procedures (Oct. 22, 1969) (115 CoNG. REC. 15193 (daily ed. Dec. 1, 1969)).

The document, Administrative Conference of the United States, Recommendations Adopted by the Administrative Conference of the United States at its Third Plenary Session, October 21-22, 1969, Washington, D.C. (Oct. 22, 1969), contains the texts of all recommendations of the October 1969 session of the Conference. Copies of the recommendations and of the supporting Committee reports can be obtained from the Office of the Chairman of the Administrative Conference, 726 Jackson Place, N.W., Washington, D.C. 20506. The recommendations may also be found in 115 CoNG. Rec. 15191 (daily ed. Dec. 1, 1969).
}

16. Atomic Energy Act of $1954 \S \S 103$ (b) \& 104(b), 42 U.S.C. $\S \S 2133(b) \& 2139$ (b) (1964).

17. 10 C.F.R. $\S 50.13$ (1969). 
to protect against the effects of enemy attacks. ${ }^{18}$ This rule has been held to be "well within the limits of the powers delegated to [the AEC] by Congress when it decided . . . to embody the policy of limitation in its regulations."19

With regard to the second subdivision in the recommendation, several agencies have placed time limits on interventions. ${ }^{20}$ Some agency rules presently provide for prehearing conferences ${ }^{21}$ and written testimony before the proceeding begins. ${ }^{22}$ Finally, the proposal to winnow out impractical and frivolous suggestions by means of a requirement that there be a threshold showing of merit for the alternative being proposed seems to find substantial support in the language of a recent case before the Court of Appeals for the District of Columbia Circuit. In Rocky Mountain Power Co. v. FPC ${ }^{23}$ that court said that it did not read Scenic Hudson and its progeny"s "to mean that the Commission must undertake an investigation and demonstration of the viability of every project submitted to it that lacks even a threshold showing that it is feasible." 25 Several other recent cases $^{26}$ seem to emphasize an agency's duty in licensing cases to explore and give proper consideration to possible alternatives to the plan proposed by the license applicant.

While clearly applicable to power plant licensing situations the significance of the recommendation for other types of licensing is difficult to assess. The agencies recently have been asked to report to the Conference Chairman on the recommendation. ${ }^{27}$

18. See statement of consideration accompanying publication of the rule in the Federal Register, 32 Fed. Reg. 13445 (1967).

19. Siegel v. AEC, 400 F.2d 778, 784 (D.C. Cir. 1968).

20. See, e.g., 18 C.F.R. $\S 1.8$ (d) (1969) (FPC); 14 C.F.R. $\S 302.15$ (c)(2) (1969) (CAB); 10 C.F.R. $\$ 2.714$ (1969) (AEC). The problem of interventions, as such, has wide significance for licensing cases and is not peculiar to the types of cases dealt with by the Committee's recommendation. For this reason the Committee's recommendation does not underlake to deal specifically with the question of interventions.

21. See, e.g., 18 C.F.R. § I.18 (1969) (FPC); 14 C.F.R. § 302.23 (1969) (CA B).

22. See, e.g., 18 C.F.R. $\S 1.26$ (c)(2)(iii) (1969) (FPC) (expert testimony); 14 C.F.R. $\S 302.24$ (b) (1969) (CAB); 10 C.F.R. § 2.743(b) (1969) (AEC).

23. 409 F.2d 1122 (D.C. Cir. 1969). See also Citizens for Allegan County, Inc. v. FPC, 414 F.2d 1125, 1133 (D.C. Cir. 1969).

24. Udall v. FPC, 387 U.S. 428 (1967); Marine Space Enclosures, Inc. v. FMC, 420 F.2d 577 (D.C. Cir. 1969); Northern Natural Gas Co. v. FPC, 399 F.2d 953 (D.C. Cir. 1968), See also Citizens for Allegan County, Inc. v. FPC, 414 F.2d 1125 (D.C. Cir. 1969).

25. 409 F. 2 d at 1129 n. 29.

26. See note 24 supra.

27. In June 1969. prior to the formal adoption of the Recommendation, the Conference 
Advance Planning for Power Plant Siting

Effective implementation of the "alternatives" recommendation should prove useful in alleviating the alternatives problem at the adjudication stage of the licensing process. However, the nature and dimensions of the problem require also that it be attacked well before the adjudicatory stage by means of advance planning. ${ }^{28} \ln$ the case of licensing of power plants, a mechanism for consideration of alternatives should be established in the advance planning process so as to facilitate reconciliation of the conflicting environmental interests and the selection of the best available site under the circumstances. Such a consideration, if properly documented, should help significantly in satisfying the doctrine enunciated in Scenic Hudson.

\section{The Problem}

The problems encountered in the Scenic Hudson case are symptomatic of the growing public concern with protecting the environment. National concern began to manifest itself in the early sixties, focusing on such areas as chemical waste and sewage in streams, and smog and smoke in the air. More recently, the thermal, radiological, and general ecological effects of proposed steam power plants have become a subject of increasing interest.

lt is unfortunate that in this new found concern for the environment another, equally imminent crisis is frequently overlooked: that of meeting this nation's accelerating needs for energy. The warning signals are readily discernible: the great Northeast blackout of 1965, power shortages in New York during the summer of 1969 , and requests in our nation's capital for voluntary curtailment of power usage. Those close to the problems of power generation believe that only a portion of the iceberg may be showing. The consumption of electricity is expected to increase three-fold by 1990 and six-fold between now and the end of the

Chairman, acting on a decision by the Council of the Conference, transmitted the Recommendation to the major licensing agencies for their consideration. The agencies were asked to report to the Chairman on possible applications of the Recommendation and steps which are or could be taken to implement it. All replies have not yet been received.

28. For a discussion of the concept of advance planning and its application in different contexts, including the siting of nuclear power plants, see Ramey, The Role of Planning in the Alomic Energy Program, 36 GeO. WASH. L. REV. 1060 (1968). 
century ${ }^{29}$ To meet this increasing demand there is no choice but to rely almost entirely on plants which use steam-driven turbine-electric generators. Hydroelectric power can no longer be viewed as a source of much additional help, except for some pumped-storage projects, because most of the good hydro sites already have been developed. Moreover, steam-electric power plants, whether nuclear or fossilfired, ${ }^{30}$ are the most effective devices for producing the vast quantities of electricity that are needed.

In order to meet projected energy needs many new and very large plants will have to be built. ${ }^{31}$ None can avoid producing some environmental effects. Hydroelectric projects-damis and pumpedstorage facilities-have a considerable impact on the environment by virtue of their size alone. Fossil-fueled plants and nuclear plants affect the environment in somewhat different ways: although both fossil-fueled and nuclear plants require cooling water and release heated liquid effluents into their surroundings, fossil-fueled plants additionally release gaseous effluents of the combustion process into the atmosphere.

The problem of environmental effects has led to generalized objections to the construction of power plants, regardless of type. As Charles F, Luce, Chairman of the Board of the Consolidated Edison Company, said in recent testimony: "So it doesn't seem to matter where the plant is located, or what kind of fuel it uses, there are serious objections. . . . The problem is we don't have the alternative of building or not building the new capacity. We have to build it and we have to build it somewhere." ${ }^{32}$ While objections can be offered to

29. See, e.g., "Nuclear Power-Facts Instead of Fiction," address by Comm'r Ramey at a briefing for news media at the Connecticut Yankee Nuclear Plant, Haddam Neck, Conn., June 2, 1969, AEC Press Release S-19-69 (June 2, 1969); "Planning for Environmcntal Protection in the Siting of Nuclear and Fossil Powered Plants," address by Comm'r Ramey, Federal Bar Association, Washington, D.C., Oct. 15, 1969, AEC Press Release S-35-69 (Oct. 21, 1969).

30. "Fossil-fired" electric generating plants include those which use coal, oil, or gas as fuel.

31. See Energy Policy Staff. Office of Science and Technology. Considerations Affecting Steam Pó́wer Plant Site Selection 4 (1968) (U.S. Government Printing Office: 1968 0-325-261) (reprinted in JOINT COMM. ON ATOMIC ENERGY. 9/sT CONG.. IST SESS., Selected Materials on Environmental Effects of Producing Electric Power 145, 160 (Comm. Print 1969)) thereinafter cited as EnERgy Policy Staff Considerations], estimating a need for 255 new sites for thermal plants, not including hydro, of 500,000 kilowatts to $2,000,000$ kilowatts in size, over the next 20 years. See also text accompanying notes 37-39 infra.

32. Hearings on Future Ownership of the.AEC's Gaseous Diffusion Plants Before the Joint Coimm. on Atomic Energy. 91 st Cong.. Ist Sess. 183-84 (1969). 
any type of plant, the nature of the licensing process applicable for the differing plant types ${ }^{33}$ can and does affect the type of intervenor and estimated licensing time faced by an applicant. These factors, in turn, can and do influence decisions on plant selection and construction. An appropriate balance of all the factors bearing on establishing a new plant needs to be struck. This point was made in recent testimony before Congress by one of the authors:

By way of background, it seems to me that the public interest requires a balancing of all of the factors associated with the establishment of large powerplants of whatever type: nuclear, coal, oil, gas, or hydro.

While the impact of such plants on our water is a significant aspect of the total picture, the problem of thermal effects is, of course, an energy problem, and not one which is unique to nuclear power.

Other aspects of the picture deserve consideration too. I have in mind such matters as air pollution, esthetics, economic development, and the need for electric power, and, of special importance with regard to ruclear plants, radiological safety."

The most promising approach toward achieving the requisite balance between the increasing need for electric power and effects on the environment would seem to lie in the improvement of planning and coordinating mechanisms for the siting of power plants. ${ }^{35}$ Some steps in this direction have already been taken. In October 1967 one of the authors called for the establishment of an interagency electric power plant siting group which could begin the planning process so vitally needed. ${ }^{36}$ This suggestion resulted in the establishment of the

33. See notes 47 to 54 infra and accompanying text.

34. Hearings on Water Pollution-1969 Before the Subcomm. on Air and Water Pollution of the Senate Comm. on Pub. Works, 91 st Cong., Ist Sess., pt. 4, at 1040 (1969) (testimony of Comm'r Ramey).

35. An improved planning process can also serve to alleviate another growing area of potential delay in the power plant licensing process. We refer to the increasing concerns being voiced on antitrust grounds to new power plant projects. See, e.g., Municipal Elec. Ass'n v. SEC, 413 F.2d 1052 (D.C. Cir. 1969); Cities of Statesville v. AEC, Civil No. 21,706 (D.C. Cir. Dec. 5, 1969) (38 U.S.L.W. 2326 (D.C. Cir. Dec. 5, 1969)); Municipal Elec. Ass'n v. FPC, Civil No. 22,385 (D.C. Cir. July 30, 1969). It is of interest in connection with the last cited case that although antitrust has not been an issue in power reactor licensing cases, it will become an issue either as a result of the requirements of section 105 of the Atomic Energy Act or the passage of new legislation. See Hearings on Practical Value Before the Joint Comm. on Atomic Energy, 9 Ist Cong., Ist Sess., (Nov. 18-20, 1969).

36. Pending the statutory establishment of coordinating mechanisms and, much as 1 dislike to suggest any more committces, a possible interim solution to this growing question is to set up a Federal Interdepartmental Committee on Electric Power Plant Siting with the purpose of developing a coordinated approach in the planning of ways to handle the many problems affecting siting. 1 have in mind a group which would be comprised of experts in all the various disciplines and factors involved in siting. Just 
interagency group ${ }^{37}$ which produced the report "Considerations Affecting Steam Power Plant Site Selection'38 under the sponsorship of the Energy Policy Staff of the Office of Science and Technology ${ }^{39}$

This report made some predictions as to future needs for electric power and plant sites for all forms of steam-electric generating facilities: nuclear, coal, oil, and gas. It estimated that at least 255 new sites will be needed in the United States for thermal plants of 500,000 kilowatts capacity or larger over the next 20 years. Of this total, 91 sites would be for fossil-fueled plants and 164 would be for nuclear plants. ${ }^{10}$ The study also pointed to the need for a balanced approach to power plant siting."

The original interagency siting group-now under the aegis of the President's Environmental Quality Council ${ }^{12}$ - has continued to evolve so that today it is actively grappling with various approaches toward resolution of the pressing problems of siting and power reliability. Public interest in power plant siting has intensified since publication of the report, and meetings are being held with representatives of organizations interested in siting problems, including the Citizens Advisory Committee on Environmental Quality, ${ }^{43}$ certain state and local governments with experience in such problems, and utility industry organizations such as the Edison

for a start, this would seem to call for people from AEC, the Department of the Interior, the Environmental Science Services Administration, the Federal Power Commission, HEW, and perhaps state and local governments. 1 would think FPC should chair such an assemblage. It also would make sense to include the Edison Electric Institute and the American Public Power Association.

"AEC's Role in National Electric Power Policy," address by Comm'r Ramey, Federal Bar Association, Washington, D.C., Oct. 16, 1967, AEC Press Release IN-827 (Oct. 23, 1967).

37. The agencies represented were the Atomic Energy Commission, the Department of Health, Education, and Welfare, the Department of the Interior, the Federal Power Commission, the Rural Electrification Administration, and the Tennessee Valley Authority.

38. Energy Policy Staff Considerations.

39. The Energy Policy Staff of the Office of Science and Technology was established at the direction of President Johnson on January 30, 1967. In a message to the Congress entitled, "Protecting Our Natural Heritage," he said: "l am directing the President's science advisor and his Office of Science and Technology to sponsor a thorough study of energy resources and to engage the necessary staff to coordinate energy policy on a governmentwide basis." 113 Cong. Rec. 1042 (daily ed. Jan. 30, 1967).

40. These figures assume that plant sizes will increase to an average of $2,000,000$ kilowatts per plant. If plants do not achieve this capacity, more sites will be required.

41. Energy Policy Staff Considerations.

42. See Exec. Order No. I1.472, 34 Fed. Reg. 8693 (1969).

43. Id. 
Electric Institute and the American Public Power Association. Proposed legislation is being carefully examined and recommendations on legislative action will be made as appropriate. Finally, a study is in progress which will identify pertinent ideas for research and development that are not currently included in the plans of involved governmental agencies, the utilities, and industry.

It should also be noted that the states are moving ahead in the planning area. California has established a Resources Agency power plant siting committee which, among other functions, coordinates the comments of all state environmental agencies concerning a power plant site proposal by a utility." New York State has. given its Atomic and Space Development Authority significant authority with respect to nuclear generating sites. ${ }^{45}$ Washington and Oregon are also taking steps to prepare for the anticipated widespread use of nuclear power for electricity generation in the Northwest. Congressmen Holifield and Hosmer of California have made some thoughtful proposals on the role of the states in cooperating with the federal government in planning large scale nuclear sites. ${ }^{.6}$

\section{Present Limitations on Regulation}

At present only hydroelectric and nuclear power projects require a federal license for plant construction,, 7 although data developed by the Corps of Engineers indicates that two-thirds of the fossil plants in excess of 400 megawatts (electrical) constructed during 1967 required some form of federal permission before they could operate. ${ }^{18}$ However, at the present time-only the hydroelectric licensing authority of the FPC may be exercised-indeed, must be exercised-so that proposed projects "will be best adapted to a comprehensive plan for improving or developing a waterway or waterways for the use or benefit of interstate or foreign commerce,

44. See CAL. Gov't Code $\S 12805$ (West 1963).

45. N.Y. Pub. Auth. Law §§ 1854-56 (McKinney 1961).

46. Congressmen Holifield and Hosmer Press Release, "Nuclear Power Parks" (Aug. 20. 1969).

47. See Federal Power Act of 1920 \$4(e), 16 U.S.C. § 797(e) (1964) (hydro licenses); Atomic Energy Act of $1954 \S \S 103-04,42$ U.S.C. $\$ \S 2133-34$ (1964) (nuclear power reactor licenses).

48. Hearings on Water Pollution-1969 Before the Subcomm. on Air and Water Pollution of the Senate Comm. on Pub. Works, 91 st Cong., 1st Sess., pt. 4, at 1047-48 (1969). The typical case involved obtaining a permit from the Corps of Engineers in order to locate cooling water intake and outfall structures on navigable waters. 
for the improvement and utilization of waterpower development, and for beneficial public uses, including recreational purposes . . . .

The regulatory authority of the Corps of 'Engineers under the Rivers and Harbors Act ${ }^{50}$ to issue dredge and fill permits and thus affect the construction of many of the larger sized steam-electric plants, ${ }^{51}$ has been held to be confined to navigational considerations and not properly exercisable for the protection of fish and wildlife.52 Similarly, the authority of the Atomic Energy Commission to license the construction of nuclear power plants $s^{53}$ has been held not to extend to the thermal effects of a nuclear plant's effluents; rather the authority is confined essentially to radiological effects.5

A reeent enactment, the National Environmental Policy Act of 1969,55 may be viewed as conferring additional regulatory authority on such licensing or "permitting" agencies as the AEC and the Corps of Engineers. Title I of the Act, among other things, directs "all agencies of the Federal Government [to] . . . include in every recommendation or report on proposals for legislation and other major Federal actions significantly affecting the quality of the human environment, a detailed statement . . . on . . . alternatives to the proposed action." ${ }^{56}$ The statute also requires that any such recommendation or report be preceded by consultation with "any Federal agency which has jurisdiction by law or special expertise with respect to any environmental impact involved." 57 Copies of comments or statements of the appropriate agency resulting from such consultation are then to be made available to the President, to the public, and to the Council on Environmental Quality provided for in Title $11 . .^{58}$ If the statute can be interpreted as extending

\footnotetext{
49. Federal Power Act of 1920, $\S 10$ (a), 16 U.S.C. $\$ 803$ (a) (1964).

50. Rivers and Harbors Act of $1899, \S 10,33$ U.S.C. $\S 403$ (1964).

51. See note 48 supra.

52. Zabel v. Tabb, 296 F. Supp. 764 (M.D. Fla. 1969).

53. See note 47 supra.

54. New Hampshire v. AEC, 406 F.2d 170 (Ist Cir.), cert. denied, 395 U.S. 962 (1969). For a description of the AEC's regulatory program see Ramey, The AEC Regulatory Program-Current Status, Future Trends, 45 N.C.L. REv. 323 (1967).

55. 83 Stat. 852 (1969 U.S. CODE CONG. \& AD. News 2712-16 (Jan. 1, 1970)).

56. Id. \& 102(C) (1969 U.S. CODE CONG. \& AD. News at 2713).

57. Id.

58. Id. (1969 U.S. CODE CONG. \& Ad. News at 2714).

There is created in the Executive Office of the President a Council on Environmental Quality (hereinafter referred to as the "Council"). The Council shail be composed of three members who shall be appointed by the President to serve at his pleasure, by and
} 
additional regulatory authority to federal licensing agencies, their licensing processes will be lengthened and a fortuitous and favorable balance will have been created for fossil-fueled plants which are not subject to any federal licensing process.

\section{Future Prospects}

The absence of some broader federal controls over the location of steam-electric power plants in the larger sizes is not likely to continue much longer. ${ }^{59}$ There are several bills presently processing through the Congress which could significantly affect power plant siting, although they are structured in broad terms and not directed at power plants alone.

Section 103 of the Muskie Water Quality Act Amendment. A bill introduced by Senator Edmund Muskie would bar the issuance of a federal license or permit until a state-issued water quality certificate had first been obtained. ${ }^{50}$ As of February 1970 the bill was before a conference committee seeking to reconcile differences in the Senate and House versions, and it is thus difficult to predict the amount of additional licensing time that may be incorporated into the bill's final version. For power reactor licenses, the normal processing time for such applications should ordinarily be enough for obtaining the required water quality certificate from the affected

with the advice and consent of the Senate. The President shall designate one of the members of the Council to serve as Chairman. Each member shall be a person who, as a result of his training, experience, and attainments, is exceptionally well qualified to analyze and interpret environmental trends and information of all kinds; to appraise programs and activities of the Federal Government in the light of the policy set forth in Title $I$ of this Act; to be conscious of and responsive to the scientific, economic, social, esthetic, and cultural needs and interests of the Nation; and to formulate and recommend national policies to promote the improvement of the quality of the environment. Id. $\$ 202$ (1969 U.S. CoDE Cong. \& AD. News at 2715).

59. It seems to have been apparent to the courts in the cases construing the regulatory authority of the Corps of Engineers and the Atomic Energy Commission that legislation to resolve such cases was on the way. In Zabel v. Tabb, 296 F. Supp. 764 (M.D. Fla. 1969), the court said: "As this opinion is being prepared [opinion dated February. 17, 1969] the Congress is in session. Advocates of eonservation are both able and effective. The way is open to obtain a remedy for future situations like this one. . . ." Id. at 771 .

In New Hampshire v. AEC, 406 F.2d 170 (1st Cir.), cert. denied, 395 U.S. 962 (1969), the court's opinion on the scope of the AEC's regulatory authority similarly referred to the fact that "the legislative branch is actively seised of the problem" of controlling the thermal effects of power plant operations. Id. at 176.

60. S. 7, 91st Cong., Ist Sess. $\S 14(b)$ (1969). The companion bill in the House is H.R. 4148,9 Ist Cong., Ist Sess. $§ 11$ (b) (1969). 
state. However, there may be a delay problem inherent in language of the Conference Committee Print of October 15, 1969, Senate version, which would allow the water quality certifying agency an entire year in which to grant or deny the certificate, ${ }^{61}$ in contrast to the House-passed version of the bill which was amended on the floor for the specific purpose of affording a "reasonable" time within which the states must act. ${ }^{62}$ The one year period, taken together with the provision for any affected state-such as states downstream-to issue water quality certificates, could well produce delays. ${ }^{63}$

In addition to this bill and numerous others on various aspects of the environment, it is likely that Congress will consider other bills dealing more directly with the problem of planning for new electric generating facilities and protecting the environment. The interagency siting group is looking at possible legislative approaches, and the solutions thus far considered range from what appear to be rather elaborate procedural designs to more modest approaches. In all events, the final selection of a power plant siting mechanism should be made only after a careful assessment of the proposal in the light of, inter alia, the effectiveness with which it can be expected to deal with the problem of delays.

The White Bill. One approach, formulated in H.R. 12585, was proposed by former Chairman Lee C. White of the FPC and grew from the work of the interdepartmental siting committee mentioned earlier. The bill was introduced by Congressman Torbert Macdonald on July 2, 1969.64 A second bill, S. 2752, was introduced by Senator Edmund Muskie on July 31, $1969 .{ }^{65}$ Both bills emphasize resolution of conflicting interests at the regional level. Nevertheless, an examination of the key provisions of each bill readily indicates that the federal regulatory hand is in the picture under $b c t h$ bills.

Under the White Bill, existing regional utility bulk power councils would be recognized or, where none exists, new ones established. Participation by all segments of the electric utility industry in the region would be required, the FPC and regional

\footnotetext{
61. S. 7, 91st Cong., Ist Sess. \& 16(c)(1)(1969).

62. 115 Cong. ReC. 2689 (daily ed. April 16, 1969).

63. Congressmen Holifield (D.-Calif.) and Edmondson (D.-Okla.) discussed this problem on the House floor. 115 CoNG. ReC. 2689-95 (daily ed. April 16, 1969).

64. 115 CONG. REC. 5587 (daily ed. July 2, 1969).

65. 115 CoNG. REC. 8909 (daily ed. July 31, 1969). Senator Muskie's remarks upon introduction of S. 2752 appear at II CONG. REC. 8909-20 (daily ed. July 31, 1969).
} 
utility commissions being represented by nonvoting members. Under the bill regional councils would be charged with the responsibility for "continuous planning." The individual long-range plans of the utilities of the region, to be developed after mandatory consultation with "Federal, State, and local agencies and any statewide siting committees concerned with the protection of the environment and land-use planning," ${ }^{66}$ would be coordinated by the regional councils. The councils would be required to report at least yearly to the Advisory Panel on the Environment-an organization which the bill would establish under the aegis of the existing Environmental Quality Council ${ }^{67}$-each state commission in the region, the National Electric Reliability Council, and the Federal Power Commission. These reports would cover a rolling ten-year period in advance of the reporting date and would be required to include, among other things, "sufficiently detailed information regarding the location and description of proposed bulk power facilities to permit the Government agencies and the public to plan accordingly." 68

In addition to requiring long-range continuous planning, the White proposal would require two years advance public notice of detailed plans for the construction of a thermal power plant, such plans to be reviewed by the Federal Power Commission and the Advisory Panel on the Environment. If suggestions generated by these reviews are not adopted, the reasons for rejection would have to be made publicly available. An important feature of the bill is the provision which would bar commencement of plant construction until the proponent has made a certification to the Federal Power Commission that the construction and operation of the plant will comply with published power reliability and engineering standards, and with "Federal, State, and local standards or guidelines for preservation and enhancement of recreation areas, historical and other important sites, and aesthetic values." ${ }^{\circ 9}$ The proponent would also have to submit certifications to the Federal Power Commission from other appropriate governmental bodies that the plant will comply with air and water quality standards, applicable public utility codes, and any requirements of law deemed by the Federal Power Commission to be appropriate subjects of certification..$^{70}$

66. H.R. 12585, 9 lst Cong.. Ist Sess. § 6(a) (1969).

67. See note 42 supra and accompanying text.

68. H.R. 12585, 9 Ist Cong.. Ist Sess. $§ 6(c)(1969)$.

69. Id. $\$ 7(()(1)(C)$.

70. Id. $\$ 7(1)(2)$. 
Most important to the present discussion, however, the bill would also require submission of a certification that the plant will meet "the terms and conditions of a specific routing or siting permit";";1 the bill specifically authorizing the issuance of such permits by the states. If no state agency has been delegated the requisite regulatory authority, ${ }^{72}$ the bill provides for the exercise of such authority by state joint boards "after public notice and opportunity for protest and hearing." 73 These boards would be created under existing provisions of the Federal Power Act ${ }^{74}$ and composed of Federal Power Commission appointees and nominees of affected state public utility commissions.

Thus, under the White Bill, the key decision on siting would be made by a state agency or a state joint board. In this respect it is of interest that the bill contains a provision to the effect that if a state joint board fails to act within a reasonable time on a matter referred to it, the matter shall be acted upon by the Federal Power Commission.

The bill further requires that the Federal Power Commission establish procedures for the submission of the required certification. These procedures must provide for public notice and opportunity to protest alleged failure to comply with a federal or state requirement which is the subject of a certification. However, any protests are referred to the affected agency for a report, and the agency's report "shall be conclusive as to the alleged noncompliance."7s

It will be noted that the White Bill does not provide, as does the next bill considered, for any additional federal license, as such. However, the required certification process would probably amount to much the same thing in actual practice.

The Muskie Planning Bill (S. 2752). The Muskie Bill would be known as the "Intergovernmental Coordination of Power Development and Environmental Protection Act." It would require that an agency designated by the President (the "agency")78 establish

71. Id. \& 7(I)(2)(C).

72. At the beginning of 1969 twenty state utility commissions exercised licensing authority over the location of power plants under their jurisdiction. ENERgy POLICY Staff Considerations Tables XI $1 \& 2$, at 80-81.

73. H.R. 12585, 9 Ist Cong., Ist Sess. § 7(g)(1969).

74. § 209, 16 U.S.C. § $824 \mathrm{~h}$ (1964).

75. H.R. 12585, 9 Ist Cong., Ist Sess. § 7(h)(1969).

76. Presumably this would be the Federal Power Commission, although the Department of the Interior and the Atomic Energy Commission have important responsibilities in the area of power development and environmental protection. 
regional districts and promulgate "criteria for the development of procedures for the siting and construction" power plants. Regional boards composed of a representative of the Governor of each state in the regional district would be established, and each regional board would appoint an intergovernmental advisory council composed of representatives of regional organizations, states, local governmental bodies, affected international agencies, the public, and all segments of the electric industry. These councils would be enjoined to "seek to stimulate maximum participation and presentation of views by persons having an interest in or affected by planning for the construction"78 of power plants. And the meetings would be required to "be open to the public with reasonable opportunity for presentation of views by any person interested in the purposes of this Act." 79 The regional boards would be required to consult with the advisory councils.

Within one year after the promulgation of the criteria by the agency each regional board would be required to prescribe, after public notice and opportunity for comment, including, specifically, -oral comment, "procedures for the application of such criteria within the region of such board," and "procedures for applying for and issuing licenses." ${ }^{80}$ These procedures would be reviewed by the agency and become the approved procedures for the region if found by the agency to be consistent with its previously established criteria. In any case where the regional board failed to promulgate procedures or propose standards acceptable to the agency, the agency would be authorized and directed to do so.

Finally, the bill would direct the agency to issue a construction license upon notification from a regional board that the proposed construction has been certified in compliance with established regional standards and procedures. ${ }^{81}$ However, a significant qualification to this direction is provided. No license would issue if "the agency, upon advice from other affected Federal agencies, finds that such construction or modification has not complied with approved procedures and standards, the purposes of this Act, or other Federal statutes or regulations."

\footnotetext{
77. S. 2752, 91 st Cong., 1st Sess. § 5(a) (1969).

78. Id. § 4(c).

79. Id.

80. Id. § $5(\mathrm{~b})$.

81. Id. \& 8(b).

82. $l$ d.
} 
From these brief descriptions it can be seen that both bills have the advantage of applying to all forms of steam electric plants and seek to set up planning devices which can resolve, at an early stage, through full participation by interestcd persons and groups, the difficult and complex environmental questions associated with power plant licensing. Resolution of these questions at the planning stage will avoid many delays in the total licensing process. It is important to note, however, that delays can readily be foreseen in following the fairly elaborate administrative approval processes of both bills.

\section{Some Suggestions}

An admittedly more modest approach that could go a long way toward avoiding Scenic Hudson problems and yet does not set up such an elaborate administrative framework is that mentioned by one of the authors in recent testimony before Congress. ${ }^{.3}$ This approach would have the following features:

(1) Utilization of regional utility councils, but ungrading them with public members;

(2) An assurance that each utility in a region, whether public or private, may join in the regional utility councils;

(3) A requirement that each utility develop and coordinate with other utilities in a given region a comprehensive plan for the expansion of bulk power facilities of 300 megawatts and above;

(4) A provision for consultation with environmental groups during the planning stage;

(5) A provision for participation by state power plant siting groups, such as the California Resources Agency power plant siting committee;

(6) The publication and submittal of coordinated proposed plans for bulk power facilities to the AEC, FPC, the Governor and state commission of each affected state, the state and federal agencies responsible for water quality, air pollution control, and land-use planning, any state-wide power plant siting agency and any other person requesting a copy.

(7) The utility would be required to give appropriate consideration to all comments received on its proposed plan and justify its rejection of any of them;

(8) A requirement that detailed plans for a facility be appropriately published in public media some reasonable period of time before construction begins-possibly 2 years.

83. Hearings on Environmental Effects of Producing Electric Power Before the Joint Comm. on Alonic Energ); 91st Cong., 1st Sess. (1969) (testimony of Comm'r Ramey Oct. 29, 1969). 
Perhaps the best planning mechanisms for the near term are the regional power supply councils established voluntarily in cooperation with the Federal Power Commission. At present the councils are concerned only with the reliability and adequacy of service. They should be upgraded and expanded both in function and membership. They should consult in their planning efforts with conservationists and other groups interested in environmental matters to enhance the likelihood that a reasonable number of clear-cut alternatives will be identified and resolved at an early date. The councils also ought to have public members and members representing all of the electric utilities in the region: large and small, public and private.

In connection with the foregoing suggestions, it is of interest that on June 25, 1969, the Federal Power Commission issued a "Statement of Policy" which provides for "actual participation on a non-voting basis by the Staff of the Commission and the State regulatory agencies in the regional council deliberations, and the deliberations of committees or working groups . . . ." Also, in this regard, Chairman Nassikas of the Federal Power Commission recently stressed the importance of coordinated planning on a regional basis to satisfy environmental considerations in the provision of needed electric power and noted with approval the FPC's Policy Statement of June 25, 1969.85 During the course of these same remarks Mr. Nassikas, while indicating he does not favor any legislation at the present time, made the following suggestion regarding the role of interstate compacts as planning devices: "The possibility of establishing interstate compacts relating to the preservation, restoration, utilization and development of our natural resources should be explored to meet environmental problems transcending state boundaries." ${ }^{86}$

\section{CONCLUSION}

It seems likely that in the next few years some legislation will be enacted to provide for more comprehensive consideration of power plant siting matters and at the same time ensure reliable and

84. FPC Docket No. R-362, "Reliability and Adequacy of Electric Service-Reporting of Data-Participation of Regulatory Personnel in Regional Councils," Statement of Policy (June 25, 1969).

85. Hearings on Environmental Effects of Producing Electric Power Before the Joint Comm. on Atomic Energy: 91st Cong., Ist Sess. (1969) (testimony of Chmn. Nassikas Oct. 28, 1969).

86. Id. 
abundant quantities of electric power. Advance planning mechanisms utilizing regional means of considering power needs in relation to environmental requirements are urgently required. Also, techniques such as those referred to in Recommendation No. 15 of the Administrative Conference ${ }^{87}$ represent procedural mechanisms which can contribute to the reduction of licensing delays once the formal licensing process has begun in power plant cases. It is to be hoped that the mechanisms ultimately established will succeed in producing decisions which reflect appropriate consideration of the alternatives and yet are rendered in a timely fashion.

87. See note 15 supra and accompanying text. 